Abstracta Iranica Abstracta Iranica

Revue bibliographique pour le domaine irano-aryen

Volume 28 | 2007

Comptes rendus des publications de 2005

Le drogman Padery émissaire de France en Perse

(1719-1725). Paris, Geuthner, 2005, 318 p., ill. (Société d'Histoire de l'Orient).

\title{
Francis Richard
}

\section{(2) OpenEdition}

1 Journals

\section{Édition électronique}

URL : http://journals.openedition.org/abstractairanica/18221

DOI : 10.4000/abstractairanica.18221

ISSN : 1961-960X

Éditeur :

CNRS (UMR 7528 Mondes iraniens et indiens), Éditions de l'IFRI

\section{Édition imprimée}

Date de publication : 15 mai 2007

ISSN : 0240-8910

\section{Référence électronique}

Francis Richard, «Le drogman Padery émissaire de France en Perse (1719-1725). Paris, Geuthner, 2005,

318 p., ill. (Société d'Histoire de l'Orient). », Abstracta Iranica [En ligne], Volume 28 | 2007, document

205, mis en ligne le 18 septembre 2007, consulté le 25 septembre 2020. URL : http://

journals.openedition.org/abstractairanica/18221 ; DOI : https://doi.org/10.4000/abstractairanica.

18221

Ce document a été généré automatiquement le 25 septembre 2020.

Tous droits réservés 


\title{
Le drogman Padery émissaire de France en Perse (1719-1725). Paris, Geuthner, 2005, 318 p., ill. (Société d'Histoire de l'Orient).
}

\author{
Francis Richard
}

1 L'ensemble de l'ouvrage d'A.-M. Touzard, préfacé par Jean Calmard (pp. 13-26), repose sur un dépouillement minutieux des archives du Ministère des Affaires étrangères (Correspondance Politique) et de dossiers conservés aux Archives nationales. Le livre est accompagné de la traduction de quatre documents officiels persans de 1715 et 1722 , avec la reproduction de trois d'entre eux. Il apporte en définitive, à l'occasion d'un épisode assez rocambolesque, un éclairage nouveau et intéressant sur les relations diplomatiques entre France et Perse à la fin de l'époque safavide. Il a pour toile de fond les rivalités inextricables entre deux groupes traditionnels d'intérêts français en Perse, la Compagnie des Indes - dont Padéry, drogman d'origine grecque, est le chargé d'affaires - et les marchands provençaux, dont Gardanne - nommé Consul de France en Perse - défend les prérogatives.

Pour le c.r. détaillé de cette publication, voir Studia Iranica 35/1, 2006.

\section{INDEX}

Thèmes : 4.2.1. Safavides et Qâjârs 
AUTEURS

FRANCIS RICHARD

Mondes iranien et indien - BULAC - Paris 